\title{
Effect of Vector Control and Foliar Nutrition on Quality of Orange Juice Affected by Huanglongbing: Chemical Analysis
}

\author{
Elizabeth Baldwin ${ }^{1}$, Jinhe Bai, Anne Plotto, John Manthey, \\ Smita Raithore, Sophie Deterre, and Wei Zhao \\ USDA/ARS Horticultural Research Laboratory, Ft. Pierce, FL 34945
}

Cecilia do Nascimento Nunes

Department of Cell Biology, Microbiology and Molecular Biology, Food Quality Laboratory, University of South Florida, Tampa, FL 33620

\section{Philip A. Stansly and James A. Tansey}

Southwest Florida Research and Education Center, University of Florida-IFAS, Immokalee, FL 34142

Additional index words. aroma volatiles, sugars, acids, limonoids, flavonoids

\begin{abstract}
Valencia' orange trees from groves with $90 \%$ infection by Candidatus liberibacter asiaticus ( $C$ Las), the presumed pathogen for citrus greening or huanglongbing (HLB) disease, were treated with insecticide $(I)$, a nutritional spray $(N)$, and insecticide plus nutritional spray $(I+N)$. Controls $(C)$ were not treated. Fruit were harvested in March to April, 2013, 2014, and 2015, juiced, and the juice was frozen for later chemical analyses. Titratable acidity (TA), soluble solids content (SSC), SSC/TA ratio, many volatiles, flavonoids, and limonoids showed differences because of season, whereas SSC, several volatiles (ethanol, cis-3 hexenol, $\alpha$-terpinene, ethyl acetate, and acetone), flavonoids (narirutin, vicenin-2, diosmin, nobiletin, heptamethoxy flavone), and limonoids (nomilin and nomilinic acid glucoside) showed differences because of treatment. However, consistent patterns for chemical differences among seasons were not detected. TA tended to be higher in $N$ and $C$ the first two seasons and SSC/TA higher in $I$ and $I+N$ for all seasons (not significant for 2014). Bitter limonoids tended to be higher in $I, N$ or $I+N$ over the seasons. Principal Component Analysis showed that there was a good separation by season overall and for treatment in 2013. In 2014 and 2015, the insecticide treatments (either $I$ or $I+N$ ) had the highest sugar and SSC/TA levels and lowest TA levels, although not always significant, as well as higher juice $C$ Las cycle threshold $(C \mathrm{t})$ levels, indicating lower levels of the pathogen.
\end{abstract}

Orange juice is the most popular fruit juice because of its flavor and more notably for nutritional benefits (De Ancos et al., 2002). Florida and California are the largest orange producing states in the U.S., with Florida oranges being mostly processed and California mostly consumed as fresh fruit. However, the future of orange fruit production

Received for publication 5 Apr. 2017. Accepted for publication 1 June 2017.

Mention of a trademark or proprietary product is for identification only and does not imply a guarantee or warranty of the product by the U.S. Department of Agriculture. The U.S. Department of Agriculture prohibits discrimination in all its programs and activities on the basis of race, color, national origin, gender, religion, age, disability, political beliefs, sexual orientation, and marital or family status.

This paper is based on a presentation given during the 2016 Annual Meeting of the Florida State Horticultural Society, which was held 12-14 June 2016, in Stuart, FL.

${ }^{1}$ Corresponding author. E-mail: liz.baldwin@ars. usda.gov. and subsequently the processing industry is highly jeopardized by citrus greening disease, or HLB, first discovered in Florida in 2005 (Bové, 2006; Gottwald, 2010; Lin et al., 2008; Shokrollah et al., 2011). Despite major research efforts, there is no cure for the disease and Florida orange production has fallen from around 244 million boxes in the 1997-98 season to 81.5 million for this past 2015-16 season (USDA-NASS, 2016). Processing plants are, therefore, not running at full capacity and face closures because of lack of fruit volume. The disease is putatively incited by the bacterium $C$ Las and is spread by the Asian citrus psyllid (ACP) vector (Diaphorina citri) which causes severe tree decline (Bové, 2006). HLB fruit that look normal (asymptomatic) generally taste like healthy fruit, but fruit that are symptomatic for HLB (small, green and misshapen) tend to be off-flavored and drop prematurely, thus, contributing to yield reductions. HLB symptomatic fruit that impart off-flavor to the juice have lower sugars, sometimes higher acids, higher levels of bitter limonoids and astringent flavonoids as well as an altered volatile profile (Baldwin et al., 2010; Dagulo et al., 2010; Plotto et al., 2010). In general, because HLB symptomatic fruit have significantly lower SSC and often higher acidity (often measured as TAs) compared with healthy fruit, they exhibit a lower soluble solids/acid ratio (SSC/TA) (Baldwin et al., 2010; Dagulo et al., 2010). The SSC/TA is often used to evaluate fruit maturity, with a lower ratio indicating immature fruit (Bassanezi et al., 2009). Based on this ratio, the quality of symptomatic fruits is similar to that of unripe fruit and hence the reported bitter and sour taste (Dea et al., 2013; Plotto et al., 2010). However, the SSC/TA tends to increase with later harvest dates, and as such, variability due to variety and harvest date were found to be higher than that due to disease (Baldwin et al., 2010). Early season fruit juice tends to be less sweet and more bitter, sour, and astringent (Dea et al., 2013; Plotto et al., 2010). Bitterness in orange fruit and juice is caused mainly by two limonoids: limonin and nomilin (Hasegawa et al., 1989). Higher concentrations of limonin and nomilin were found in the juice from asymptomatic and even more so from HLB symptomatic fruit compared with healthy fruit (Baldwin et al., 2010).

Many growers are coping with HLB by controlling the psyllid vector (Stansly et al., 2010, 2014; Tansey et al., 2016) with insecticides and managing tree disease symptoms with foliar nutrient sprays (Giles, 2011; Tansey et al., 2016). Foliar applications deliver micronutrients to counteract HLBinduced deficiencies (Masuoka et al., 2011), salts of phosphorus acid to aid in nutrient assimilation and compounds such as salicylic acid, that are thought to activate systemic acquired resistance pathways (SAR) in the tree. Insect vector control and foliar nutrient/ SAR treatments increased yields in the sampled blocks, and thus were purported to lessen disease expression in these same trees (Stansly et al., 2014; Tansey et al., 2016). The objective of this study was to investigate whether the preharvest vector control (insecticide) and foliar nutrient sprays would also mitigate HLB-induced off-flavor symptoms in the fruit and juice, as exhibited by flavor and aroma chemical profiles.

\section{Materials and Methods}

Field treatments. Experiments were carried out on a 5.2-ha grove located in Collier Co., Florida, planted in 2001 with Citrus sinensis (L.) Osbeck cv. Valencia, on Swingle citrumelo, C. paradisi Macf. $\times$ Poncirus trifoliata L., rootstock. Planting density was 373 trees $\cdot \mathrm{ha}^{-1}\left(151\right.$ trees $\left.\cdot \mathrm{ac}^{-1}\right)$ at $7.3 \mathrm{~m}$ between rows and $3.7 \mathrm{~m}$ within rows (Stansly et al., 2014; Tansey et al., 2016). Trees were irrigated with undertree, microsprinklers, and standard weed control and fertilization practices were followed (Davies and Jackson, 2009). The grove was over $90 \%$ infected with HLB within 18 months of commencing treatments in 2008 as ascertained by sampling every fifth tree previously for $\mathrm{qPCR}$ 
detection by method of $\mathrm{Li}$ et al. (2006). The grove was divided into 16 plots in a randomized complete block (RCB) design with two factors: insecticide and foliar nutrients, each at two levels (with and without) (Stansly et al., 2014). Treatments included insecticide applications $(I)$ as needed for ACP control, 23 applications of foliar nutrition $(N)$, a combination of insecticide plus foliar nutrition $(I+N)$, and an untreated control $(C)$. Each treatment was replicated four times (Stansly et al., 2014).

Insecticide treatments were applied twice during the dormant seasons and during the growing seasons based on a threshold of 0.2 adults per tap sample in 2012 and 0.1 per tap in 2013-15 (Tansey et al., 2016). Insecticide treatments were grouped by growing season from the end of harvest through the beginning of harvest the next year. The two dormant spray applications of broad-spectrum insecticides were made to the entire study site in the winter of 2012-13 and to $I$ and $I+N$ treatment trees only during growing seasons and the winters of 2013-14 and 2014-15 (Table 1). Foliar nutrition was applied during major flush periods (spring, summer, and fall) when leaves were fully expanded but not yet hardened (Stansly et al., 2014; Tansey et al., 2016), with slight differences in the nutrition program in the 2012 to Sept. 2013 than for the rest of the experimental period (included Bacillus subtilis and boron) (Table 2).

Fruit sampling. All mature 'Valencia' fruit were harvested and weighed by plot mid-March to late-April of 2013, 2014, and 2015 (Tansey et al., 2016). For 2013, a subsample of four bags of fruit subsamples (replicates per treatment were 151-283 fruit/bag-replicate) were delivered to the USDA-ARS Horticultural Research Laboratory and stored at $10{ }^{\circ} \mathrm{C}$ for $1-2$ weeks until washed and juiced using a JBT extractor (JBT FoodTech, Lakeland, FL) then pasteurized (Model 25DH; MicroThermics Inc., Raleigh, NC) at $92{ }^{\circ} \mathrm{C}$ for $18 \mathrm{~s}$ and the resulting juice frozen until chemical analyses. Before juicing, a bag of control fruit was used to prime the juicer. The situation was similar for 2014 and 2015, but the juicing was done at the USDA laboratory using a JBT juicer and MicroThermics pasteurizer. After washing, fruit were juiced using a fresh juicer (Fresh'n Squeeze ${ }^{\circledR}$ Point-of-Sale Juicer; JBT FoodTech), and pasteurized using a pilot pasteurizer (UHT/HTST Laboratory 25EHV Hybrid; Microthermics Inc.) at $90{ }^{\circ} \mathrm{C}$ for $10 \mathrm{~s}$.

Quantification of sugars and acids. For quality determination, SSC and TA of the control and blends were determined before individual sugar and acid analyses. SSC, determined by refractive index, was measured with a digital ATAGO PR-101 refractometer (Atago Co, Tokyo, Japan), and TA and $\mathrm{pH}$ were calculated from titration of $10 \mathrm{~mL}$ of juice with $0.1 \mathrm{~mol} \cdot \mathrm{L}^{-1} \mathrm{NaOH}$ to a $\mathrm{pH} 8.1$ endpoint using an 808 Titrando (Metrohm, Riverview, FL).

Individual sugars were analyzed with a high-performance liquid chromatography (HPLC) system following an optimized extraction of the juice samples (Baldwin et al., 2012). Twenty grams of juice samples was centrifuged (Avanti J-E centrifuge; Beckman-Coulter, Brea, CA) at 11,952 $g_{n}$ for $20 \mathrm{~min}$ at $10^{\circ} \mathrm{C}$. A total of $10 \mathrm{~mL}$ of the supernatant was passed through a C-18 Sep-Pak (Waters/Millipore), and the eluate was filtered with a $0.45 \mu \mathrm{m}$ Millipore (SiemensMillipore, Shrewbury, MA) filter before analysis using HPLC. The column used was a Sugar-Pak ${ }^{\mathrm{TM}} \mathrm{I}(10 \mu \mathrm{m}, 6.5 \mathrm{~mm} \times 300 \mathrm{~mm})$ (Waters, Milford, MA) operated at $90{ }^{\circ} \mathrm{C}$ in a CH-30 column heater and a TC-50 controller (FIAtron, Milwaukee, WI). The samples were analyzed by injecting $60 \mu \mathrm{L}$ of the filtered juice using a Perkin-Elmer Series 200 autosampler and pump (Perkin-Elmer, Waltham, MA) and running through an isocratic system of $0.001 \mathrm{~mol} \cdot \mathrm{L}^{-1}$ CaEDTA mobile phase with a flow rate of $0.3 \mathrm{~mL} \cdot \mathrm{min}^{-1}$. Detection of peaks was done with an Agilent 1100 series refractive index detector (Agilent Technologies, Santa Clara, CA). Quantification was based on the external standard method (Version 3.3.2. SP2; EZChrom Elite software, Santa Clara, CA) using standards for sucrose, glucose, and fructose. All results are expressed as $\mathrm{g} / 100 \mathrm{~mL}$ of juice. The sugars sucrose, glucose, and fructose were added to give total sugars, and the glucose and fructose values were multiplied by 0.74 and 1.73 , respectively, to normalize to sucrose for sweetness and then added to sucrose to give sucrose equivalents (Koehler and Kays, 1991).

Organic acids were also analyzed using HPLC of the same extracts that were prepared for the individual sugars. Chromatographic separation was done with an AltechOA1000 Prevail organic acid column $(9 \mu \mathrm{m}, 300 \mathrm{~mm} \times 6.5 \mathrm{~mm}$ ) (Grave Davison Discovery Sciences, Deerfield, IL). The samples were introduced to the HPLC system by injecting $60 \mu \mathrm{L}$ at a flow rate of $0.2 \mathrm{~mL} \cdot \mathrm{min}^{-1}$ at $35^{\circ} \mathrm{C}$ and a mobile phase of $0.005 \mathrm{~mol} \cdot \mathrm{L}^{-1}$ $\mathrm{H}_{2} \mathrm{SO}_{4}$. The analytes of interest (citric and malic acids) were detected with a Spectra System ultraviolet 6000 LP photo diode array detector (Thermo Fisher Scientific, Waltham, MA). Quantification was based on the calibration curves for standards of citric and malic acids, expressed as $\mathrm{g} / 100 \mathrm{~mL}$ of juice.

Total ascorbic acid was quantified by mixing $2 \mathrm{~g}$ of homogenate with $20 \mathrm{~mL}$ metaphosphoric acid mixture $\left(6 \% \mathrm{HPO}_{3}\right.$ containing $2 \mathrm{~N}$ Acetic acid). The samples were then filtered $(0.22 \mu \mathrm{m})$ before HPLC analysis. Ascorbic acid analysis was conducted using a Hitachi LaChromUltra UHPLC system with a diode array detector and a LaChromUltra C18 $2 \mu \mathrm{m}$ column $(2 \mathrm{~mm} \times$ $50 \mathrm{~mm}$ ) (Hitachi Ltd., Tokyo, Japan). The analysis was performed under isocratic mode at a flow rate of $0.5 \mathrm{~mL} \cdot \mathrm{min}^{-1}$ with absorbance measured at $254 \mathrm{~nm}$. Sample injection volume was $5 \mu \mathrm{L}$, each with duplicate HPLC injections. Mobile phase was buffered potassium phosphate monobasic $\left(\mathrm{KH}_{2} \mathrm{PO}_{4}, 0.5 \%\right.$, $\mathrm{w} / \mathrm{v})$ at $\mathrm{pH} 2.5$ with metaphosphoric acid $\left(\mathrm{HPO}_{3}, 0.1 \%, \mathrm{w} / \mathrm{v}\right)$. The retention time of the ascorbic acid peak was $2.5 \mathrm{~min}$. After comparison of retention time with the ascorbic acid standard, the peak was identified. The

Table 1. Insecticides applied to $I$ (insecticide-treated) and $I+N$ (insecticide + nutrition-treated) trees from 2012 to $2015{ }^{z}$

\begin{tabular}{|c|c|c|c|c|c|}
\hline Date & Brand name & Active ingredient & Rate/ha & $\mathrm{HMO}^{\mathrm{y}}(\%)$ & Company \\
\hline 1 May 2012 & Movento ${ }^{(B)}$ MPC $^{\mathrm{x}}$ & Spirotetramat & $1.17 \mathrm{~L}$ & 2 & Bayer CropScience LP \\
\hline 15 June 2012 & Imidan $^{\circledR} 70-\mathrm{W}$ & Phosmet & $1.12 \mathrm{~kg}$ & 1 & Gowan Company \\
\hline 16 Aug. 2012 & Dimethoate $4 \mathrm{EC}^{\mathrm{x}}$ & Dimethoate & $1.75 \mathrm{~L}$ & 2 & Helena Chemical \\
\hline 8 Nov. 2012 & Delegate $^{\circledR} \mathrm{WG}^{\mathrm{x}}$ & Spinetoram & $0.37 \mathrm{~kg}$ & 1 & Dow AgroSciences LLC \\
\hline 5 Dec. 2012 & Danitol $^{\circledR} 2.4 \mathrm{EC}^{\mathrm{w}}$ & Fenpropathrin & $1.17 \mathrm{~L}$ & - & Valent \\
\hline 24 Jan. 2013 & Movento $^{\circledR} \mathrm{MPC}^{\mathrm{w}}$ & Spirotetramat & $1.17 \mathrm{~L}$ & 2 & Bayer CropScience LP \\
\hline 10 Apr. 2013 & VoliamFlexi $^{\circledR \mathrm{x}}$ & Thiamethoxam + Chlorantraniliprole & $0.51 \mathrm{~kg}$ & 1 & Syngenta \\
\hline 31 Oct. 2013 & Closer $^{\mathrm{TM}} \mathrm{SC}$ Insecticide ${ }^{\mathrm{x}}$ & Sulfoxaflor & $0.37 \mathrm{~L}$ & 3 & Dow AgroSciences LLC \\
\hline 19 Dec. 2013 & $\operatorname{Imidan}^{\circledR} 70-\mathrm{W}^{\mathrm{w}}$ & Phosmet & $1.12 \mathrm{~kg}$ & 1 & Gowan Company \\
\hline 22 Jan. 2014 & Danitol $^{\circledR} 2.4 \mathrm{EC}^{\mathrm{w}}$ & Fenpropathrin & $1.17 \mathrm{~L}$ & 一 & Valent \\
\hline 22 Mar. 2014 & Mustang $^{\circledR x}$ & Zeta-Cypermethrin & $0.31 \mathrm{~L}$ & - & FMC Corporation \\
\hline 7 July 2014 & Exirel $^{\circledR \mathrm{x}}$ & Cyantraniliprole & $1.46 \mathrm{~L}$ & - & Du Pont \\
\hline 19 Dec. 2014 & Lorsban $^{\circledR}$ Advanced $^{\mathrm{w}}$ & Chlorpyrifos & $5.85 \mathrm{~L}$ & 1 & Dow AgroSciences LLC \\
\hline 14 Jan. 2015 & Baythroid $^{\circledR} \mathrm{XL}^{\mathrm{w}}$ & Fenpropathrin & $0.44 \mathrm{~L}$ & - & Bayer CropScience LP \\
\hline 1 May 2015 & Agri-Flex $^{\circledR x}$ & Thiamethoxam + Abamectin & $0.62 \mathrm{~L}$ & 1 & Bayer CropScience LP \\
\hline 27 July 2015 & Apta $^{\circledR x}$ & Tolfenpyrad & $1.82 \mathrm{~L}$ & - & Ninchino America Inc \\
\hline
\end{tabular}

zTansey et al. (2016).

${ }^{\mathrm{y}} \mathrm{HMO}=$ horticultural mineral oil.

${ }^{\mathrm{x}}$ Growing season sprays.

${ }^{\mathrm{w}}$ Dormant spray sprays. 
Table 2. Components of foliar nutrition applications in 2012-15. ${ }^{\mathrm{z}}$

\begin{tabular}{|c|c|c|c|c|}
\hline & Product & Function & Rate/ha & Company \\
\hline \multirow[t]{9}{*}{2012 to Sept. 2013} & Serenade Max WP (Bacillus subtilis $26.2 \%$ ) & SAR inducer & $2.52 \mathrm{~kg}$ & AgraQuest, Inc. \\
\hline & Saver(Potassium salicylate) & SAR inducer & $2.34 \mathrm{~L}$ & Plant Food Systems \\
\hline & $3-18-20 \mathrm{w} / \mathrm{K}-\mathrm{Phite}^{\circledR}\left(\mathrm{KH}_{2} \mathrm{PO}_{3}+\mathrm{K}_{2} \mathrm{HPO}_{3}\right)$ & Macronutrient/Fungicide & $74.83 \mathrm{~L}$ & Plant Food Systems \\
\hline & $13-0-44$ fertilizer $\left(\mathrm{KNO}_{3}\right)$ & Macronutrient & $9.53 \mathrm{~kg}$ & Diamond R Fertilizer \\
\hline & Techmangam $\left(\mathrm{MnS}_{4}\right)$ & Micronutrient & $9.53 \mathrm{~kg}$ & Diamond R Fertilizer \\
\hline & Zinc Sulfate & Micronutrient & $3.14 \mathrm{~kg}$ & Diamond R Fertilizer \\
\hline & Sodium Molybdate & Micronutrient & $0.06 \mathrm{~kg}$ & Diamond R Fertilizer \\
\hline & Epsom Salts $\left(\mathrm{MgSO}_{4}\right)$ & Micronutrient & $9.53 \mathrm{~kg}$ & Diamond R Fertilizer \\
\hline & Purespray Green ${ }^{\circledR}$ (435 Oil) & Adjuvant & $46.77 \mathrm{~L}$ & Petro-Canada Lubricants, Inc. \\
\hline \multirow[t]{9}{*}{ Oct. 2013 to Sept. 2015} & Saver ${ }^{\mathrm{TM}}$ (Potassium salicylate) & SAR inducer & $9.35 \mathrm{~L}$ & Plant Food Systems \\
\hline & K-Phite ${ }^{\circledR}\left(\mathrm{KH}_{2} \mathrm{PO}_{3}+\mathrm{K}_{2} \mathrm{HPO}_{3}\right)$ & Fungicide & $4.68 \mathrm{~L}$ & Plant Food Systems \\
\hline & $13-0-44$ fertilizer $\left(\mathrm{KNO}_{3}\right)$ & Macronutrient & $9.53 \mathrm{~kg}$ & Diamond R Fertilizer \\
\hline & Techmangan $\left(\mathrm{MnSO}_{4}\right)$ & Micronutrient & $9.53 \mathrm{~kg}$ & Diamond R Fertilizer \\
\hline & Zinc Sulfate & Micronutrient & $3.14 \mathrm{~kg}$ & Diamond R Fertilizer \\
\hline & Sodium Molybdate & Micronutrient & $0.06 \mathrm{~kg}$ & Diamond R Fertilizer \\
\hline & Epsom Salts $\left(\mathrm{MgSO}_{4}\right)$ & Micronutrient & $9.53 \mathrm{~kg}$ & Diamond R Fertilizer \\
\hline & Purespray Green $^{\circledR}$ (435 Oil) & Adjuvant & $46.77 \mathrm{~L}$ & Petro-Canada Lubricants, Inc. \\
\hline & Beau-Ron ${ }^{\circledR} \mathrm{D}$ (Boron) & Micronutrient & $1.68 \mathrm{~kg}$ & Drexel Chemical Co. \\
\hline
\end{tabular}

${ }^{\mathrm{z}}$ Tansey et al. (2016).

amount of total ascorbic acid content in orange juice was quantified using calibration curves obtained from different concentrations $(10,20,30,50,100,150,200$, and $300 \mu \mathrm{g} \cdot \mathrm{mL}^{-1}$ ) of ascorbic acid standards.

Quantification of limonoids and flavonoids. Concentrations of limonoids and flavonoids in orange juice were determined using highperformance liquid chromatography - mass spectrometry (HPLC-MS) following a previous method (Baldwin et al., 2010). Each juice sample $(10 \mathrm{~mL})$ was added to $30 \mathrm{~mL}$ of methanol and $70 \mu \mathrm{L}$ of $1.8 \mathrm{mg} \cdot \mathrm{mL}^{-1}$ mangerifin (internal standard). After manually shaking 60 times, the mixture was incubated at $55^{\circ} \mathrm{C}$ for $15 \mathrm{~min}$ in a shaking incubator (130 rpm), and then exposed to a $-20{ }^{\circ} \mathrm{C}$ freezer for $5 \mathrm{~min}$. The cooled mixture was centrifuged at $15,000 g_{\mathrm{n}}$ for $15 \mathrm{~min}$ at $5{ }^{\circ} \mathrm{C}$, and the supernatant was collected. The pellets were extracted again with $10 \mathrm{~mL}$ of DI water and $30 \mathrm{~mL}$ of methanol by repeating the above shaking, incubation, and centrifuging regimen. The supernatants were merged, and concentrated using a rotary evaporator to yield $2.5 \mathrm{~mL}$ extract. The concentrated sample was then passed through a $0.45 \mu \mathrm{m}$ PTFE filter for HPLC-MS analysis. A Waters 2695 Alliance HPLC (Waters, Medford, MA) connected in parallel with a Waters 996 PDA detector and a Waters/ Micromass ZQ single quadrupole mass spectrometer equipped with an electrospray ionization source was used for the analysis. Compound separations were achieved with a Waters Atlantis dC18 column $(2.1 \mathrm{~mm} \times$ $100 \mathrm{~mm}$ ), using solvent gradient conditions as reported previously (Baldwin et al., 2010). Elution conditions included a binary solvent gradient composed initially of $0.1 \mathrm{~mL}$ formic $\mathrm{acid} / 100 \mathrm{~mL}$ water, and acetonitrile (90/10 v/v) and increased with linear gradients to $85 / 15$ $(\mathrm{v} / \mathrm{v})$ over $10 \mathrm{~min}$, then to $75 / 25(\mathrm{v} / \mathrm{v}), 60 / 40$ $(\mathrm{v} / \mathrm{v})$, and $30 / 70(\mathrm{v} / \mathrm{v})$ over 15,23 , and 40 min, respectively, and finally equilibrating to the initial condition of $90 / 10(\mathrm{v} / \mathrm{v})$ over $60 \mathrm{~min}$, at a flow rate of $0.75 \mathrm{~mL} \cdot \mathrm{min}^{-1}$. Postcolumn split to the PDA and mass ZQ detector was 10:1. MS parameters were as follows: ionization mode, $\mathrm{ES}^{+}$; capillary voltage $3.0 \mathrm{kV}$, extractor voltage $5 \mathrm{~V}$; source temperature $100{ }^{\circ} \mathrm{C}$; desolvation temperature $225{ }^{\circ} \mathrm{C}$; desolvation $\mathrm{N}_{2}$ flow $465 \mathrm{~L} \cdot \mathrm{h}^{-1}$; cone $\mathrm{N}_{2}$ flow $70 \mathrm{~L} \cdot \mathrm{h}^{-1}$. Protonated ions $[\mathrm{M}+\mathrm{H}]^{+}$ were monitored in scan mode. Quantification was based on the calibration curves for authentic standards of each flavonoid and limonoid compounds analyzed and expressed as $\mathrm{g} / 100 \mathrm{~mL}$ of juice.

Quantification of aroma volatiles. Three milliliters of juice was transferred to a $10-\mathrm{mL}$ crimp-capped vial at the pilot plant, transported on ice to the laboratory, and then stored at $-80{ }^{\circ} \mathrm{C}$. Frozen samples were thawed under running tap water and injected onto an Agilent 6890 (Agilent Technologies) gas chromatography (GC) using a Gerstel multipurpose autosampler equipped with Stabilwax and HP-5 low bleed columns. The flow rate was split equally to the two columns at $17 \mathrm{~mL} \cdot \mathrm{min}^{-1}$ at $40{ }^{\circ} \mathrm{C}$ with an increase in temperature at $6{ }^{\circ} \mathrm{C} \cdot \mathrm{min}^{-1}$ up to $180{ }^{\circ} \mathrm{C}$, where the temperature was held constant for an additional $5.8 \mathrm{~min}$. The GC peaks for the aroma volatile compounds were quantified using standard curves as determined by enrichment of deodorized orange juice by known concentrations of authentic volatile compound standards (Baldwin et al., 2010). Volatile compound identification was confirmed using a headspace and solid phase microextraction (SPME) fibers along with mass spectroscopy (MS) following the methods described by Bai et al. (2014). Briefly, the juice samples were incubated for $30 \mathrm{~min}$ at $40{ }^{\circ} \mathrm{C}$. A 2-cm SPME fiber (50/30 $\mu \mathrm{m} \mathrm{DVB/Carboxen/PDMS;} \mathrm{Supelco,}$ Bellefonte, PA) was then exposed to the headspace for $30 \mathrm{~min}$ at $40{ }^{\circ} \mathrm{C}$. After exposure, the SPME fiber was inserted into the injector of a GC-MS (Model 6890; Agilent) to desorb the extract for $15 \mathrm{~min}$ at $250{ }^{\circ} \mathrm{C}$. The GC-MS equipment and settings were as follows: DB-5 (60 m length, $0.25 \mathrm{~mm}$ i.d., $1.00 \mu \mathrm{m}$ film thickness; J\&W Scientific, Folsom, CA) columns, coupled with a MS detector (5973 N; Agilent). Mass units were monitored from 30 to $250 \mathrm{~m} / \mathrm{z}$ and ionized

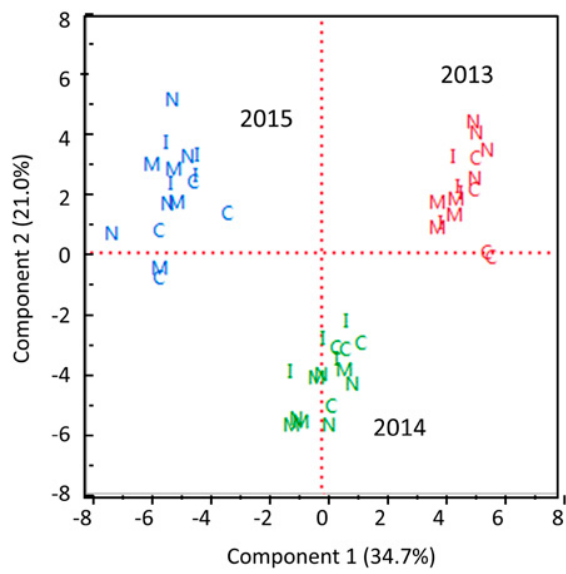

Fig. 1. Principle component analysis plot of all four preharvest treatments of 'Valencia' orange trees including untreated control $(C)$, foliar nutritional sprays $(N)$, Insecticide sprays $(I), I+N(M)$ for all 3 years (February-March harvests in 2013, 2014 and 2015) for 55 attributes that were measured postharvest in fruit juice and included 12 sugar and acid measurements, 26 aroma volatiles, and 17 secondary metabolites (flavonoids or limonoids).

at $70 \mathrm{eV}$. Data were collected using a data system (ChemStation G1701 AA; HewlettPackard, Palo Alto, CA). A mixture of C-5 to C-18 n-alkanes was run at the beginning of each day to calculate retention indices.

$D N A$ extraction and $q P C R$ detection of $C$ Las from juice. DNA was extracted from $500 \mu \mathrm{L}$ of orange juice using a modified CTAB method as described in a patent publication (Zhao et al., 2015). DNA quality $(260 / 280$ and 260/230 ratio) and quantity were assessed using spectrophotometry (NanoDrop; Thermo Scientific). CLas detection was accomplished by qPCR. Specific primers targeting CLas 16S rRNA gene (Li primers) (Li et al., 2006) or CLas hyv1 (LJ primers) (Morgan et al., 2012) were synthesized by Integrated DNA Technologies, Inc. (Coralville, IA). PCR mixtures with a total volume of $15 \mu \mathrm{L}$ contained $7.5 \mu \mathrm{L}$ of TaqMan 
PCR master mix (Applied Biosystems) for Li primers, or SYBR Green PCR Master Mix (Applied Biosystems) for LJ primers, $250 \mathrm{nM}$ each primer, $150 \mathrm{nM}$ probe (for $\mathrm{Li}$ primers) and $100 \mathrm{ng}$ of template DNA. Realtime PCR amplifications were performed in a 7500 real-time PCR system (Applied Biosystems, Foster City, CA). The qPCR parameters were as follows: $95{ }^{\circ} \mathrm{C}$ for $10 \mathrm{~min}$, followed by 40 cycles at $95{ }^{\circ} \mathrm{C}$ for $15 \mathrm{~s}$, and $60{ }^{\circ} \mathrm{C}$ for $1 \mathrm{~min}$, with fluorescence signal capture at each stage of $60{ }^{\circ} \mathrm{C}$. For SYBR ${ }^{\circledR}$ Green Real-Time PCR (with LJ primers), the default Melt Curve (disassociation) stage is continued after the 40 cycles of PCR. Ct values were analyzed using ABI 7500 Software version 2.0.6 (Applied Biosystems, Inc., Carlsbad, CA) with a manually set threshold at 0.02 and automated baseline settings.

Statistics. Principle component analysis (PCA), which is a method for projecting the 55 attributes space onto a few dimension space, was conducted for each season and across all seasons using JMP (version 11.2.0; SAS Institute, Cary, NC). SAS (version 9.4; SAS Institute) was used for all other analysis. (a) PCA scores plot

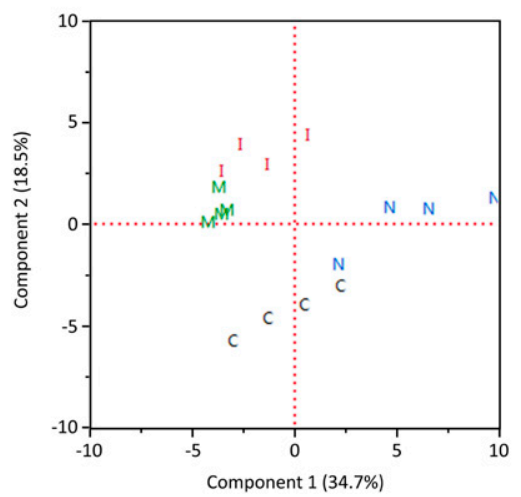

Analysis of variance (ANOVA) for each measurement was done separately for each year and for the 3 years combined. For the analyses of each individual year, an RCB design with three replicates was used. Mean separations were accomplished using Tukey's test $(P<0.05)$. For the analyses of the 3-year combined data, the design was a $2(I) \times 2(N)$ factorial, with a split plot over years.

\section{Results and Discussion}

Overall, there were differences by season, regardless of treatment, as can be expected because of environmental conditions and cumulative effects of both treatment and disease. In a previous publication involving the same treatments, the yields were highest on $I+N$ trees followed by $I$ trees, followed by $N$ trees and finally $C$ trees (Tansey et al., 2016). A PCA plot using all the chemical data measured in the orange juice samples showed groupings by year (Fig. 1), with the first two principal components explaining $55.7 \%$ of the data, for all the treatments combined.
Fig. 2. Principle component analysis (PCA) for year 2013 for four preharvest treatments of 'Valencia' orange trees including untreated control $(C)$, foliar nutritional sprays $(N)$, insecticide sprays $(I)$ and $I+$ $N(M)$ (a, PCA scores plot) for 55 attributes that were measured postharvest in the fruit juice and included 12 sugar and acid measurements, 26 aroma volatiles, and 17 secondary metabolites (flavonoids and limonoids) (b, PCA loading plot).
Component three explained an additional $11.6 \%$ of the variation (data not shown).

Overall, only the year 2013 showed separation for chemical compounds by treatment. This is seen in a PCA (Fig. 2), explaining $53.2 \%$ of the variation in the first two components, with component three explaining an additional $14 \%$ of the variation (data not shown). The first two components show $C$ and $N$ separating from each other and both from $I$ and $I+N$. The $N$ treatment was correlated with $\mathrm{pH}$, TA, citric and malic acids, aroma volatiles $\gamma$-terpinene, $\alpha$-terpineol, 2 methyl propanol, and limonene as well as with many flavonoids. The untreated $C$ was correlated with SSC, TA, SSC/TA, and many aroma volatiles. Treatments $I$ and $I+N$ correlated with the volatiles hexanol, methyl butanoate, methanol, $\alpha$-terpineol, linalool, and somewhat with SSC/TA.

For 2013, there were differences for all sugar and acid measurements except for $\mathrm{pH}$ and malic acid (Table 3). Treatment $N$ was highest in TA, SSC, sucrose, glucose, fructose, total sugars, sucrose equivalents, and citric acid. Treatment $N$ compound levels were not always significantly higher than $I$ or $I+N$ but were all significantly higher than untreated $C$, whereas $I+N$ was highest in SSC/TA among the treatments. SSC, glucose, fructose, sucrose, total sugars, and sucrose equivalents (where the sweeting power of glucose and fructose are normalized to sucrose) indicate or impart sweetness, whereas TA, citric, malic, and to some extent ascorbate, impart sourness to orange juice. For 2014, there again were no differences for $\mathrm{pH}$ and treatment $N$ was again highest in TA (along with $C$ ) and SSC (although the differences were very small between $C, I$, and $N$ ), there was no difference in SSC/TA, whereas $I$ was highest in sucrose, glucose, fructose, total sugars, and sucrose equivalents (in contrast to 2013 where $N$ was highest and now is lowest in these for 2014) as well as citric and malic acids (along with $C$ ). For 2015 , there were no differences in $\mathrm{pH}$ or malic acid, as for 2013 and 2014, nor for SSC or fructose. Treatment $I+N$ was lowest in

Table 3. Effect of insecticide, nutritional spray, or both during growth season on contents of sugar and acid measurements in 'Valencia' orange juice over three harvest seasons.

\begin{tabular}{|c|c|c|c|c|c|c|c|c|c|c|c|c|}
\hline \multirow[b]{2}{*}{ Attribute } & \multicolumn{4}{|c|}{2013} & \multicolumn{4}{|c|}{2014} & \multicolumn{4}{|c|}{2015} \\
\hline & Control & $\begin{array}{c}\text { Insecticide } \\
(I)\end{array}$ & $\begin{array}{l}\text { Nutrition } \\
(N)\end{array}$ & $I+N$ & Control & $\begin{array}{c}\text { Insecticide } \\
(I)\end{array}$ & $\begin{array}{l}\text { Nutrition } \\
(N)\end{array}$ & $I+N$ & Control & $\begin{array}{c}\text { Insecticide } \\
(I)\end{array}$ & $\begin{array}{l}\text { Nutrition } \\
(N)\end{array}$ & $I+N$ \\
\hline$\overline{\mathrm{pH}}$ & $4.1^{\mathrm{z}}$ & 4.1 & 4.2 & 4.1 & 4.1 & 4.1 & 4.1 & 4.1 & 4.2 & 4.3 & 4.2 & 4.3 \\
\hline $\begin{array}{l}\text { Soluble solids } \\
\text { content }(\mathrm{SSC}, \%)\end{array}$ & $11.0 \mathrm{~b}$ & $10.0 \mathrm{c}$ & $11.4 \mathrm{a}$ & $10.9 \mathrm{~b}$ & $10.4 \mathrm{ab}$ & $10.2 \mathrm{ab}$ & $10.7 \mathrm{a}$ & $9.9 \mathrm{~b}$ & 9.8 & 10.3 & 10.4 & 9.5 \\
\hline $\mathrm{SSC} / \mathrm{TA}$ & $16.2 \mathrm{~b}$ & $15.4 \mathrm{c}$ & $15.6 \mathrm{c}$ & $16.5 \mathrm{a}$ & 13.6 & 14.2 & 13.7 & 13.5 & $13.8 \mathrm{~b}$ & $15.7 \mathrm{a}$ & $15.1 \mathrm{~b}$ & $15.1 \mathrm{~b}$ \\
\hline Fructose (\%) & $1.9 \mathrm{~b}$ & $2.3 \mathrm{ab}$ & $2.6 \mathrm{a}$ & $2.1 \mathrm{ab}$ & $2.2 \mathrm{ab}$ & $2.3 \mathrm{a}$ & $1.8 \mathrm{c}$ & $2.0 \mathrm{~b}$ & 2.2 & 2.4 & 2.3 & 2.4 \\
\hline Total sugars (\%) & $7.2 \mathrm{~b}$ & $9.0 \mathrm{ab}$ & $9.9 \mathrm{a}$ & $8.4 \mathrm{ab}$ & $7.9 \mathrm{ab}$ & $8.6 \mathrm{a}$ & $6.5 \mathrm{c}$ & $7.3 \mathrm{~b}$ & $7.8 \mathrm{~b}$ & $8.7 \mathrm{ab}$ & $8.7 \mathrm{ab}$ & $9.0 \mathrm{a}$ \\
\hline $\begin{array}{l}\text { Sucrose } \\
\quad \text { equivalence (SE) }\end{array}$ & $8.2 \mathrm{~b}$ & $10.3 \mathrm{ab}$ & $11.3 \mathrm{a}$ & $9.5 \mathrm{ab}$ & $8.9 \mathrm{ab}$ & $9.7 \mathrm{a}$ & $7.3 \mathrm{c}$ & $8.3 \mathrm{~b}$ & $8.9 \mathrm{~b}$ & $9.9 \mathrm{ab}$ & $9.9 \mathrm{ab}$ & $10.2 \mathrm{a}$ \\
\hline Citric acid (\%) & $0.42 \mathrm{~b}$ & $0.41 \mathrm{~b}$ & $0.87 \mathrm{a}$ & $0.48 \mathrm{~b}$ & $0.80 \mathrm{a}$ & $0.80 \mathrm{a}$ & $0.50 \mathrm{~b}$ & $0.66 \mathrm{~b}$ & $0.67 \mathrm{ab}$ & $0.61 \mathrm{~b}$ & $0.73 \mathrm{a}$ & $0.70 \mathrm{ab}$ \\
\hline Malic acid (\%) & 0.13 & 0.11 & 0.17 & 0.14 & $0.18 \mathrm{a}$ & $0.18 \mathrm{a}$ & $0.15 \mathrm{~b}$ & $0.16 \mathrm{~b}$ & 0.25 & 0.24 & 0.24 & 0.23 \\
\hline
\end{tabular}

${ }^{\mathrm{z}}$ Mean values $(n=4)$ followed by different letters in the same attributes and same year (row) are significantly different at $P \leq 0.05$ using Tukey's test. 
TA, treatment $I$ was highest in SSC/TA, and either $N$ or $I+N$ highest in sucrose, glucose, total sugars, or sucrose equivalents with $N$ being highest in citric acid. Overall, this is somewhat similar to 2013 . There were no significant differences for total ascorbic acid, which was analyzed in 2014 and 2015 and ranged from 14.5 to $32.7 \mathrm{mg} / 100 \mathrm{~g}$, with no significant differences because of treatment (data not shown).

For aroma volatiles in 2013, there were no differences for acetaldehyde, octanal, or 2-methyl propanol (Table 4). Treatment $I$ was highest in methanol along with $I+N$, octanol, linalool, and $\alpha$-terpineol. Treatment $N$ was highest in hexanal, decanal, ethanol (along with $C$ ), terpinene-4-ol, $\alpha$-pinene, sabinene, myrcene (along with $C$ ), limonene (along with $C$ ), $\gamma$-terpinene, ethyl butanoate, ethyl hexanoate, and acetone (the last three along with $C$ and acetone along with $I+N$ ). Other than already mentioned, treatment $I+N$ was highest in hexanol and methyl butanoate. In 2014, there was little relationship to 2013 aroma volatile levels, except again, there were no differences for acetaldehyde or 2-methyl propanol and unlike in 2013, there were differences for octanal. In addition to octanal, there were also differences for hexanal, methanol, ethanol, hexanol, cis-3-hexanol, $\alpha$-pinene, limonene, $\gamma$-terpinene, valencene, ethyl acetate, methyl butanoate, and ethyl butanoate as in 2013; however, different treatments showed elevated levels as compared with 2013. For 2015, aroma volatiles, decanal, octanol, linalool, terpiene-4-ol, $\alpha$-pinene, sabinene, myrcene, limonene, $\gamma$-terpinene, valencene ethyl acetate, methyl butanoate, ethyl hydroxyhexanoate, and acetone showed no differences among treatments, which was completely different from 2013 and 2014. Acetaldehyde, which showed differences unlike 2013 and 2014, hexanal was highest in treatment $I$ as was hexanal (as in 2014), and octanal was highest in $N$ and $I+N$, methanol was lowest in $I+N$, and ethanol and 2-methyl propanol were highest in $I$ with cis-3-hexenol showing high levels in $C$, as in 2013 and 2014 ,

Table 4. Effects of insecticide, nutritional spray, or both during growth season on contents $\left(\mu \mathrm{L} \cdot \mathrm{L}^{-1}\right)$ of aroma volatile compounds in 'Valencia' orange juice over three harvest seasons.

\begin{tabular}{|c|c|c|c|c|c|c|c|c|c|c|c|c|}
\hline \multirow[b]{2}{*}{ Attribute } & \multicolumn{4}{|c|}{2013} & \multicolumn{4}{|c|}{2014} & \multicolumn{4}{|c|}{2015} \\
\hline & Control & $\begin{array}{c}\text { Insecticide } \\
(I)\end{array}$ & $\begin{array}{l}\text { Nutrition } \\
(N)\end{array}$ & $I+N$ & Control & $\begin{array}{c}\text { Insecticide } \\
(I)\end{array}$ & $\begin{array}{l}\text { Nutrition } \\
(N)\end{array}$ & $I+N$ & Control & $\begin{array}{c}\text { Insecticide } \\
(I)\end{array}$ & $\begin{array}{l}\text { Nutrition } \\
(N)\end{array}$ & $I+N$ \\
\hline Acetaldehyde & $14.8^{\mathrm{z}}$ & 14.7 & 14.9 & 14.8 & 11.2 & 10.5 & 10.6 & 10.2 & $8.8 \mathrm{ab}$ & $10.5 \mathrm{a}$ & $8.9 \mathrm{ab}$ & $7.8 \mathrm{~b}$ \\
\hline Decanal & $0.86 \mathrm{ab}$ & $0.89 \mathrm{ab}$ & $0.91 \mathrm{a}$ & $0.74 \mathrm{~b}$ & 0.66 & 0.58 & 0.59 & 0.69 & 0.39 & 0.32 & 0.32 & 0.32 \\
\hline Methanol & $204 \mathrm{~b}$ & 249 a & $190 \mathrm{c}$ & $246 \mathrm{a}$ & $116 \mathrm{a}$ & $87 \mathrm{~b}$ & $100 \mathrm{~b}$ & $90 \mathrm{~b}$ & $61.2 \mathrm{a}$ & $59.6 \mathrm{a}$ & $61.5 \mathrm{a}$ & $50.5 \mathrm{~b}$ \\
\hline Ethanol & $948 \mathrm{a}$ & $840 \mathrm{~b}$ & $898 \mathrm{a}$ & $810 \mathrm{~b}$ & $813 \mathrm{a}$ & $606 \mathrm{~b}$ & $614 \mathrm{~b}$ & $542 \mathrm{c}$ & $715 \mathrm{ab}$ & $689 \mathrm{ab}$ & 749 a & $594 \mathrm{~b}$ \\
\hline cis-3-Hexenol & $0.44 \mathrm{a}$ & $0.40 \mathrm{~b}$ & $0.41 \mathrm{ab}$ & $0.39 \mathrm{~b}$ & $0.38 \mathrm{a}$ & $0.34 \mathrm{~b}$ & $0.32 \mathrm{~b}$ & $0.34 \mathrm{~b}$ & $0.30 \mathrm{a}$ & $0.28 \mathrm{a}$ & $0.23 \mathrm{~b}$ & $0.25 \mathrm{~b}$ \\
\hline Octanol & $1.7 \mathrm{~b}$ & $1.8 \mathrm{a}$ & $1.7 \mathrm{~b}$ & $1.5 \mathrm{c}$ & 1.6 & 1.7 & 1.8 & 1.9 & 1.3 & 1.3 & 1.4 & 1.4 \\
\hline Linalool & $0.92 \mathrm{~b}$ & $1.15 \mathrm{a}$ & $1.00 \mathrm{ab}$ & $0.95 \mathrm{~b}$ & 0.64 & 0.59 & 0.59 & 0.60 & 0.66 & 0.65 & 0.65 & 0.54 \\
\hline Terpinen-4-ol & $0.39 \mathrm{~b}$ & $0.42 \mathrm{ab}$ & $0.45 \mathrm{a}$ & $0.36 \mathrm{~b}$ & 0.20 & 0.17 & 0.19 & 0.20 & 0.27 & 0.27 & 0.25 & 0.23 \\
\hline$\alpha$-Terpineol & $0.44 \mathrm{~b}$ & $0.62 \mathrm{a}$ & $0.40 \mathrm{~b}$ & $0.44 \mathrm{~b}$ & 0.48 & 0.47 & 0.44 & 0.49 & 0.60 & 0.73 & 0.63 & 0.60 \\
\hline$\alpha$-Pinene & $1.9 \mathrm{~b}$ & $1.7 \mathrm{c}$ & $2.1 \mathrm{a}$ & $1.7 \mathrm{c}$ & $1.4 \mathrm{~b}$ & $1.5 \mathrm{a}$ & $1.4 \mathrm{~b}$ & $1.4 \mathrm{~b}$ & 1.5 & 1.4 & 1.5 & 1.3 \\
\hline Sabinene & $1.6 \mathrm{~b}$ & $1.2 \mathrm{c}$ & $2.1 \mathrm{a}$ & $1.2 \mathrm{c}$ & 2.1 & 1.9 & 1.9 & $1.6^{*}$ & 0.94 & 0.95 & 0.73 & 0.80 \\
\hline Methyl butanoate & $0.011 \mathrm{~d}$ & $0.016 \mathrm{~b}$ & $0.013 \mathrm{c}$ & $0.027 \mathrm{a}$ & $0.023 \mathrm{a}$ & $0.015 \mathrm{~b}$ & $0.016 \mathrm{~b}$ & $0.018 \mathrm{~b}$ & 0.009 & 0.016 & 0.016 & 0.012 \\
\hline Ethyl butanoate & $0.42 \mathrm{a}$ & $0.37 \mathrm{~b}$ & $0.43 \mathrm{a}$ & $0.35 \mathrm{~b}$ & $0.31 \mathrm{a}$ & $0.19 \mathrm{~b}$ & $0.19 \mathrm{~b}$ & $0.21 \mathrm{ab}$ & $0.19 \mathrm{ab}$ & $0.22 \mathrm{a}$ & $0.22 \mathrm{a}$ & $0.17 \mathrm{~b}$ \\
\hline Ethyl hexanoate & $0.044 \mathrm{a}$ & $0.034 \mathrm{~b}$ & $0.044 \mathrm{a}$ & $0.033 \mathrm{~b}$ & 0.012 & 0.013 & 0.014 & 0.016 & $0.014 \mathrm{a}$ & $0.013 \mathrm{a}$ & $0.008 \mathrm{~b}$ & $0.011 \mathrm{~b}$ \\
\hline $\begin{array}{l}\text { Ethyl } \\
\text { 3-hydroxyhexanoate }\end{array}$ & $82.3 \mathrm{a}$ & $75.1 \mathrm{~b}$ & $72.7 \mathrm{~b}$ & $73.7 \mathrm{~b}$ & 53.7 & 53.8 & 47.6 & 51.1 & 71.1 & 86.1 & 81.6 & 83.2 \\
\hline Acetone & $0.29 \mathrm{a}$ & $0.16 \mathrm{~b}$ & $0.26 \mathrm{a}$ & $0.28 \mathrm{a}$ & 0.17 & 0.13 & 0.13 & 0.08 & 0.11 & 0.09 & 0.09 & 0.10 \\
\hline
\end{tabular}

${ }^{\mathrm{z}}$ Mean values $(n=4)$ followed by different letters in the same attributes and same year (row) are significantly different at $P \leq 0.05$ using Tukey's test.

Table 5. Effects of insecticide, nutritional spray, or both during growth season on contents (mg. $\left.\mathrm{L}^{-1}\right)$ of flavonoid and limonoid compounds in 'Valencia' orange juice over three harvest seasons.

\begin{tabular}{|c|c|c|c|c|c|c|c|c|c|c|c|c|}
\hline \multirow[b]{2}{*}{ Attribute } & \multicolumn{4}{|c|}{2013} & \multicolumn{4}{|c|}{2014} & \multicolumn{4}{|c|}{2015} \\
\hline & Control & $\begin{array}{c}\text { Insecticide } \\
(I)\end{array}$ & $\begin{array}{c}\text { Nutrition } \\
(N)\end{array}$ & $I+N$ & Control & $\begin{array}{c}\text { Insecticide } \\
(I)\end{array}$ & $\begin{array}{c}\text { Nutrition } \\
(N)\end{array}$ & $I+N$ & Control & $\begin{array}{c}\text { Insecticide } \\
(I)\end{array}$ & $\begin{array}{l}\text { Nutrition } \\
(N)\end{array}$ & $I+N$ \\
\hline Hesperidin & $96^{z}$ & 104 & 109 & 92 & 194 & 213 & 218 & 175 & 92 & 101 & 100 & 97 \\
\hline Vicenin-2 & $25 \mathrm{ab}$ & $22 \mathrm{ab}$ & $26 \mathrm{a}$ & $21 \mathrm{~b}$ & $38 \mathrm{a}$ & $39 \mathrm{a}$ & $38 \mathrm{a}$ & $33 \mathrm{~b}$ & 26 & 27 & 26 & 26 \\
\hline $\begin{array}{l}\text { Isosakuranetin } \\
\text { rutinoside }\end{array}$ & $9.5 \mathrm{~b}$ & $8.8 \mathrm{~b}$ & $12.3 \mathrm{a}$ & $8.6 \mathrm{~b}$ & $7.8 \mathrm{~b}$ & $9.8 \mathrm{a}$ & $10.0 \mathrm{a}$ & $8.5 \mathrm{~b}$ & 8.6 & 9.9 & 10.5 & 10.9 \\
\hline Diosmin & $1.1 \mathrm{~b}$ & $1.1 \mathrm{~b}$ & $1.2 \mathrm{a}$ & $1.0 \mathrm{~b}$ & $1.1 \mathrm{ab}$ & $1.4 \mathrm{a}$ & $1.1 \mathrm{ab}$ & $0.7 \mathrm{~b}$ & 1.1 & 1.2 & 1.1 & 0.9 \\
\hline Nobiletin & $2.7 \mathrm{~b}$ & $2.6 \mathrm{~b}$ & $3.2 \mathrm{a}$ & $2.5 \mathrm{~b}$ & $4.3 \mathrm{~b}$ & $3.5 \mathrm{bc}$ & $5.6 \mathrm{a}$ & $2.5 \mathrm{c}$ & 2.7 & 2.6 & 3.2 & 2.5 \\
\hline Heptamethoxyflavone & $2.1 \mathrm{~b}$ & $2.2 \mathrm{~b}$ & $2.7 \mathrm{a}$ & $2.0 \mathrm{~b}$ & $2.1 \mathrm{~b}$ & $2.4 \mathrm{ab}$ & $3.2 \mathrm{a}$ & $2.0 \mathrm{~b}$ & $2.1 \mathrm{~b}$ & $2.2 \mathrm{~b}$ & $2.7 \mathrm{a}$ & $2.0 \mathrm{~b}$ \\
\hline Limonin & $1.6 \mathrm{c}$ & $3.7 \mathrm{a}$ & $3.9 \mathrm{a}$ & $2.2 \mathrm{~b}$ & $1.8 \mathrm{ab}$ & $1.5 \mathrm{~b}$ & $2.4 \mathrm{a}$ & $2.1 \mathrm{ab}$ & $2.2 \mathrm{ab}$ & $2.2 \mathrm{ab}$ & $2.0 \mathrm{~b}$ & $2.4 \mathrm{a}$ \\
\hline Limonin glucoside & $63 \mathrm{ab}$ & $65 \mathrm{ab}$ & $67 \mathrm{a}$ & $60 \mathrm{~b}$ & $163 \mathrm{a}$ & $151 \mathrm{ab}$ & $163 \mathrm{a}$ & $140 \mathrm{~b}$ & 66 & 67 & 69 & 70 \\
\hline Nomilin & $0.10 b c$ & $0.26 \mathrm{a}$ & $0.16 \mathrm{~b}$ & $0.08 \mathrm{c}$ & $0.06 \mathrm{c}$ & $0.18 \mathrm{a}$ & $0.16 \mathrm{a}$ & $0.10 \mathrm{~b}$ & 0.13 & 0.12 & 0.10 & 0.19 \\
\hline Nomilinic acid glucoside & $183 \mathrm{ab}$ & $181 \mathrm{ab}$ & $232 \mathrm{a}$ & $161 \mathrm{~b}$ & $291 \mathrm{a}$ & $286 \mathrm{~b}$ & $293 \mathrm{a}$ & $292 a b$ & $162 \mathrm{~b}$ & $187 \mathrm{a}$ & $167 \mathrm{~b}$ & $186 \mathrm{a}$ \\
\hline $\begin{array}{l}\text { Deacetyl nomilinic } \\
\text { acid glucoside }\end{array}$ & $4.4 \mathrm{~b}$ & $5.5 \mathrm{a}$ & $6.1 \mathrm{a}$ & $5.2 \mathrm{~b}$ & $3.2 \mathrm{ab}$ & $3.5 \mathrm{a}$ & $3.1 \mathrm{ab}$ & $2.7 \mathrm{~b}$ & 4.7 & 5.2 & 5.6 & 5.2 \\
\hline
\end{tabular}

${ }^{\mathrm{z}}$ Mean values $(n=3)$ followed by different letters in the same attributes and same year (row) are significantly different at $P \leq 0.05$ using Tukey's test. 
Table 6. Attributes which were significantly affected by insecticide and nutritional sprays over three seasons.

\begin{tabular}{|c|c|c|c|c|c|c|c|}
\hline \multirow[b]{3}{*}{ Attribute } & \multirow{2}{*}{\multicolumn{2}{|c|}{$\begin{array}{c}\text { Mean value } \\
\text { Insecticide }(I)\end{array}$}} & \multicolumn{5}{|c|}{ ANOVA ( $F$ value and significance) } \\
\hline & & & \multicolumn{2}{|c|}{ Nutrition $(N)$} & \multirow[b]{2}{*}{$I$} & \multirow[b]{2}{*}{$N$} & \multirow[b]{2}{*}{$I+N$} \\
\hline & No & Yes & No & Yes & & & \\
\hline Titratable acidity (TA, \%) & 0.73 & 0.67 & & & $11.4 * * *$ & & \\
\hline Soluble solids content (SSC, \%) & 10.6 & 10.1 & & & $6.3^{*}$ & & \\
\hline Ethanol & 789.6 & 680.3 & & & $6.2 *$ & & \\
\hline$\alpha$-Terpineol & 0.50 & 0.56 & & & $4.2 *$ & & \\
\hline Sabinene & 1.57 & 1.26 & & & $4.1 *$ & & \\
\hline Vicenin-2 & 29.8 & 27.9 & & & $4.1^{*}$ & & \\
\hline Ethyl acetate & & & 0.14 & 0.11 & & $4.3 *$ & \\
\hline Diosmin & & & 1.16 & 1.02 & & $5.2 *$ & \\
\hline Hesperidin & 134.9 & 130.4 & 133.4 & 132.0 & & & $14.2 * * *$ \\
\hline Narirutin & 20.6 & 20.1 & 20.0 & 20.7 & & & $5.4^{*}$ \\
\hline Heptamethoxyflavone & 2.48 & 2.13 & 2.18 & 2.43 & & & $4.1 *$ \\
\hline Limonin & 2.31 & 2.37 & 2.18 & 2.51 & & & $4.7^{*}$ \\
\hline Nomilin & 0.120 & 0.154 & 0.141 & 0.133 & & & $7.7 * *$ \\
\hline
\end{tabular}

$*, * *, * * *$ Significant at $P \leq 0.05,0.01$, and 0.001

\section{Li primers}

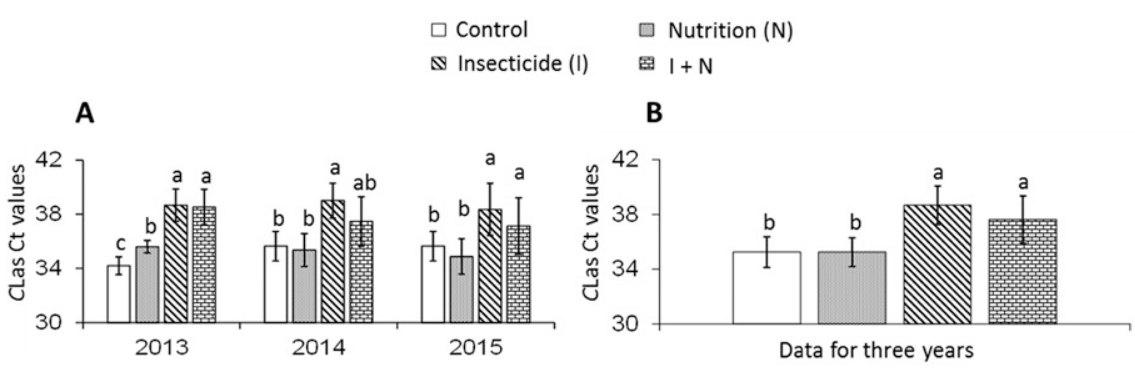

\section{LJ primers}

$$
\begin{aligned}
& \square \text { Control } \square \text { Nutrition (N) } \\
& \mathbb{\Delta} \text { Insecticide (I) 回 I+N }
\end{aligned}
$$
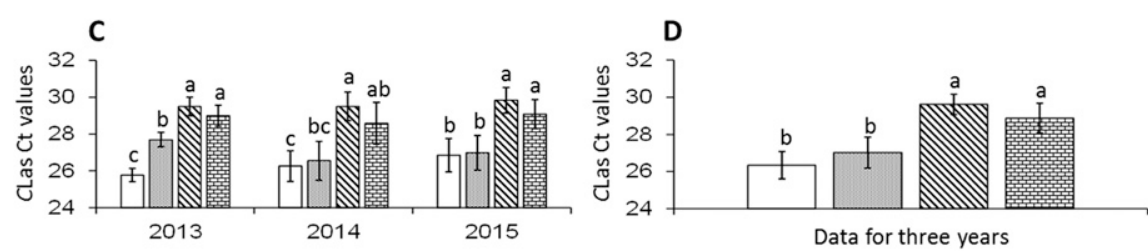

Fig. 3. Cycle threshold $(C \mathrm{t})$ values from qPCR of orange juice from fruit harvested from 'Valencia' orange trees, untreated (controls) or treated preharvest with foliar nutritional sprays $(N)$, insecticide sprays $(I)$ or $I+N$. Different letters in the same year (A and $\mathbf{C}$ ) indicate significant differences between treatments, and different letters (B and $\mathbf{D})$ indicate significant differences between treatments according to Tukey's test at $P<0.05$. (A and $\mathbf{B}$ ) are $C$ t values using Li primers, and $(\mathbf{C}$ and $\mathbf{D})$ are $C$ t values using LJ primer.

along with $I$. Ethyl butanoate was highest in $I$ and $N$, whereas ethyl hexanoate showed high levels in $C$, as in 2013, and in $I$. Otherwise, there was no consistency in aroma values across the years. The aroma volatiles analyzed in this study are reported to contribute to orange juice flavor, although there is no one odor-active compound. Aldehydes, and esters particularly, contribute giving green, citrus, and fruity aromas along with terpenoid hydrocarbons (Perez-Cacho and Rouseff, 2008).

For flavonoids in 2013, there were no differences for hesperidin, narirutin, vicenin-2, diosmin, sinesetin, tangeretin, and nobiletin. Treatment $N$ was highest in isokuranetin rutinoside, heptamethoxyflavone, limonin (along with $I$ ), limonin glucocide, nomilinic acid glucoside, and deacetyl nomilinic acid glucoside (along with $I$ ) (Table 5). Other than already mentioned, $I$ was highest in nomilin. Treatment $I+N$ was intermediate in most secondary metabolites, but lowest in nomilin, whereas untreated $C$ was lowest in limonin. Limonin and nomilin impart bitterness to orange juice, whereas the flavonoids impart mostly astringency (Horowitz and Gentili, 1969; Manners, 2007). The 2014 flavonoid and limonoid measurements had more compounds showing differences among treatments including vicinen-2, diosmin, tangeretin, and nobiletin, which did not show differences in 2013. For these compounds and the other compounds that showed differences in 2013, either $I, N$, or both showed the highest values, although not always significantly different from $C$ or $I+N$. For 2015, only sinensetin, tangeretin, heptamethoxyflavone, limonin, and nomilinic acid glucoside showed differences among treatments. For sinensetin, tangeretin, and heptamethoxyflavone, $I$ or $N$ were highest; for limonin and nomilinic acid glucoside, $I$ or $I+N$ were highest.

Regarding the main effects of $I$ or $N$, the sugar and acid measurements TA and SSC were lower with $I$, along with the volatiles ethanol, $\alpha$-terpineol, sabinene, and vicenin-2, which were lower with $I$ except for $\alpha$-terpineol (Table 6). Meanwhile, the volatile ethyl acetate and flavonoid diosmin were both lower for $N$. The flavonoids hesperidin (lower), narirutin (higher), hepetamethoxyflavone (lower) as well as the limonoids, limonin (higher), and nomilin (lower) for $N$ were all also significant for $I+N$.

Measurement of $C$ Las levels using qPCR of the juice, expressed as $C t$ values, generally showed a significant effect of insecticide treatments for both primers used (Fig. 3). Although initially leaves of every fifth tree had been tested to determine that the grove sites were more than $90 \%$ infected, the sectors of the tree can differ in CLas levels, and the effect of insecticides preventing subsequent infections also can affect subsequent $C$ Las levels. Therefore, we tested the fruit juice to see how infected the fruit were. Because there is much less nucleic acid material in juice than in leaves, the LJ primer (Fig. 3C and D) (Morgan et al., 2012) was used in addition to the Li primer (Fig. 3A and B) ( $\mathrm{Li}$ et al., 2006), as it is more sensitive because of the higher copy number of target genes (a prophage embedded numerous times in the $C$ Las genome). Figure $3 \mathrm{~A}$ and $\mathrm{C}$ show that insecticide treatments $(I$ and $I+N)$ were generally lower in CLas infection indicated by higher $C \mathrm{t}$ values. Treatments $I$ and $I+N$ were always significantly different from controls, with $I$ being significantly different from $N$ as well. Over all 3 years (Fig. 3B and D), both insecticide treatments $(I$ and $I+N)$ had higher $C t$ values (lower $C$ Las levels) than $C$ or $N$.

In conclusion, this study investigated whether foliar nutritional, insecticide, or both treatments of orange trees affected by HLB could improve flavor as determined by measuring flavor-related chemicals. The $I, N$, and $I+N$ preharvest treatments of orange trees 
did not have a consistent postharvest effect on flavor chemicals in the subsequent fruit juice over the 3 years of the study. Across the years, total sugars, TA, SSC/TA, and the bitter limonoids (limonin and nomilin), the most important taste predictors (sweetness, sourness, and bitterness) affected by HLB (Raithore et al., 2015; Plotto et al., 2010), were similar in 2013 and 2015, dipping slightly (sugars and bitter limonoids) or increasing slightly (TA) in 2014 (Tables 3 and 5 ), thus showing no trend. Therefore, it is not likely that these treatments consistently impacted flavor by raising sugar levels or reducing concentrations of acids, bitter limonoids, or both. Neither were there any significant trends in aroma compounds. However, in 2014 and 2015, either $I$ or $I+N$ had the highest sugar and SSC/TA levels and lowest TA levels, although not always significantly different from $C$ (TA) or $N$ (SSC/TA), suggesting a cumulative effect of the treatments over the years. The chemical results are reflected in sensory results (Plotto et al., 2017) of the same samples, which were not consistent but showed that $I$ or $I+N$ were associated with positive orange juice characteristics (orange, fruit flavor, and sweetness), especially in 2015. Thus, use of insecticides (with or without nutritional treatment) seemed to improve flavor. In addition, the insecticide treatments $(I$ and $I+N)$ did seem to have a consistent effect on $C \mathrm{t}$ values indicating lower CLas levels for those treatments (Fig. 3). There is evidence that CLas titer is correlated to flavor quality (Zhao et al., 2015). These results are consistent with previously reported beneficial effects on yield (Stansly et al., 2014; Tansey et al., 2016).

\section{Literature Cited}

Bai, J., E.A. Baldwin, J. Hearn, R. Driggers, and E. Stover. 2014. Volatile profile comparison of USDA sweet-orange-like hybrids vs. 'Hamlin' and 'Ambersweet'. HortScience 49:12621267.

Baldwin, E., A. Plotto, J. Manthey, G. McCollum, J. Bai, M. Irey, R. Cameron, and G. Luzio. 2010. Effect of liberibacter infection (huanglongbing disease) of citrus on orange fruit physiology and fruit/fruit juice quality: Chemical and physical analyses. J. Agr. Food Chem. 58: $1247-1262$.

Baldwin, E.A., J. Bai, A. Plotto, R. Cameron, G. Luzio, J. Narciso, J. Manthey, W. Widmer, and B.L. Ford. 2012. Effect of extraction method on quality of orange juice: Handsqueezed, commercial-fresh squeezed and processed. J. Sci. Food Agr. 92:2029-2042.

Bassanezi, R.B., L.H. Montesino, and E.S. Stuchi. 2009. Effects of huanglongbing on fruit quality of sweet orange cultivars in Brazil. Eur. J. Plant Pathol. 125:565-572.

Bové, J.M. 2006. Huanglongbing: A destructive, newly-emerging, century-old disease of citrus. J. Plant Pathol. 88:7-37.

Dagulo, L., M.D. Danyluk, T.M. Spann, M.F. Valim, R. Goodrich-Schneider, C. Sims, and R. Rouseff. 2010. Chemical characterization of orange juice from trees infected with citrus greening (huanglongbing). J. Food Sci. 75: C199-C207.

Davies, F.S. and L.K. Jackson. 2009. Citrus growing in Florida. Univ. Fla. Press, Gainesville, FL.

De Ancos, B., S. Sgroppo, L. Plaza, and M.P. Cano. 2002. Possible nutritional and health-related value promotion in orange juice preserved by high-pressure treatment. J. Sci. Food Agr. 82(8):790-796.

Dea, S., A. Plotto, J.A. Manthey, S. Raithore, M. Irey, and E. Baldwin. 2013. Interactions and thresholds of limonin and nomilin in bitterness perception in orange juice and other matrices. J. Sens. Stud. 28:311-323.

Giles, F. 2011. An alternative approach. Florida Grower Magazine. 31 Aug. 2011.

Gottwald, T.R. 2010. Current epidemiological understanding of citrus huanglongbing. Annu. Rev. Phytopathol. 48:119-139.

Hasegawa, S., R.D. Bennett, Z. Harman, C.H. Fong, and P. Ou. 1989. Limonoid glucosides in citrus. Phytochemistry 28(6):1717-1720.

Horowitz, R.M. and B. Gentili. 1969. Taste and structure in phenolic glycosides. J. Agr. Food Chem. 17:696-700.

Koehler, P.E. and S.J. Kays. 1991. Sweet potato flavor: Quantitative and qualitative assessment of optimum sweetness. J. Food Qual. 14:241-249.

Li, W., J.S. Hartung, and L. Levy. 2006. Quantitative real-time PCR for detection and identification of Candidatus Liberibacter species associated with citrus huanglongbing. J. Microbiol. Methods 66:104-115.

Lin, H., H. Doddapaneni, X. Bai, J. Yao, X. Zhao, and E. Civerolo. 2008. Acquisition of uncharacterized sequences from Candidatus Liberibacter, an unculturable bacterium, using an improved genomic walking method. Mol. Cell. Probes 22:30-37.

Manners, G.D. 2007. Citrus limonoids: Analysis, bioactivity, and biomedical prospects. J. Agr. Food Chem. 55:8285-8294.

Masuoka, Y., A. Pustika, S. Subandiyah, A. Okada, E. Hanundin, B. Purwanto, M. Okuda, Y. Okada, A. Saito, P. Holford, A. Beattie, and T. Iwanami. 2011. Lower concentrations of microelements in leaves of citrus infected with 'Candidatus Liberibacter asiaticus'. Jpn. Agr. Res. Q. 45:269-275.

Morgan, J.K., L. Zhou, W. Li, R.G. Shatters, M. Keremane, and Y.P. Duan. 2012. Improved real-time PCR detection of 'Candidatus Liberibacter asiaticus' from citrus and psyllid hosts by targeting the intragenic tandem-repeats of it's prophage genes. Mol. Cell. Probes 26(2): 90-98.

Perez-Cacho, P.R. and R.L. Rouseff. 2008. Fresh squeezed orange juice odor: A review. Crit. Rev. Food Sci. Nutr. 48:681-695.

Plotto, A., E.A. Baldwin, J. Bai, J. Manthey, S. Raithore, S. Deterre, and W. Zhao. 2017. Effect of vector control and foliar nutrition on the quality of orange juice affected by Huanglongbing: Sensory evaluation. HortScience 52:1092-1099.

Plotto, A., E. Baldwin, G. McCollum, J. Manthey, J. Narciso, and M. Irey. 2010. Effect of liberibacter infection (huanglongbing or "Greening" Disease) of citrus on orange juice flavor quality by sensory evaluation. J. Food Sci. 75: S220-S230.

Raithore, S., S. Dea, A. Plotto, J. Bai, J. Manthey, J. Narciso, M. Irey, and E. Baldwin. 2015. Effect of blending Huanglongbing (HLB) disease affected orange juice with juice from healthy orange on flavor quality. Lebensm. Wiss. Technol. 62:868-874.

Shokrollah, H., T.L. Abdullah, K. Sijam, and S.N.A. Abdullah. 2011. Identification of physical and biochemical characteristics of mandarin (Citrus reticulata) fruit infected by Huanglongbing (HLB). Austral. J. Crop Sci. 5(2):181-186.

Stansly, P.A., H.A. Arevalo, J.A. Qureshi, M.A. Jones, K. Hendricks, P.D. Roberts, and F.M. Roka. 2014. Vector control and foliar nutrition to maintain economic sustainability of bearing citrus in Florida groves affected by huanglongbing. Pest Mgt. Sci. 70:414-426.

Stansly, P.A., H.A. Arevalo, and M. Zekri. 2010. Area-wide psyllid sprays in Southwest Florida: An update on the cooperative program aimed at controlling the HLB vector. Citrus Ind. 91:6-8.

Tansey, J.A., P. Vanaclocha, C. Monzo, M. Jones, and P.A. Stansly. 2016. Costs and benefits of insecticide and foliar nutrient applications to HLB-infected citrus trees. Pest Mgt. Sci. 73: 904-916.

USDA NASS. 2016. Citrus forecast. USDA, National Agricultural Statistics Service, <http:// www.nass.usda.gov/Statistics_by_State/Florida/ Publications/Citrus/cit/2015-16/cit0516. pdf $>$.

Zhao, W., E. Baldwin, J. Bai, A. Plotto, and M. Irey. 2015. Method for assessing juice/cider quality and/or safety. U.S. Patent Application Publication US 2015/0093755 A1. 